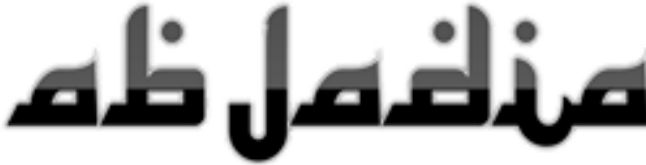

International Journal of Education

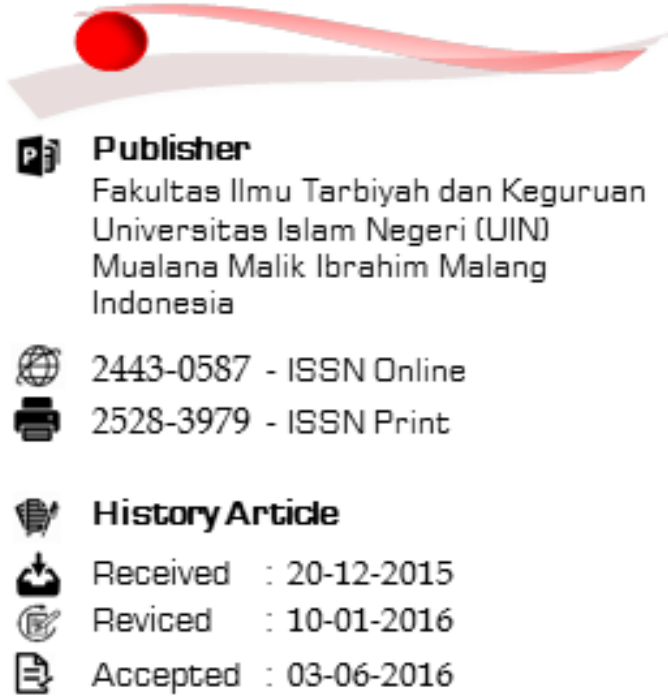

dx.doi.org/10.18860/abj.v1i1.3256

http://ejournal.uin-malang.ac.id/index.php/ abjadia/article/view/3256
Dian Mustika Anggraini, Muhammad Walid

Indonesia

\section{DEVELOPING INTERACTIVE FLASH MEDIA FOR THEMATIC LEARNING}

\section{貿, Abstract}

This research is aimed at portraying the development of interactive flash-media to boost the young learners' comprehension about the learning theme of energy saving that is inserted in thematic learning. Interactive media are necessary to promote different learning satisfaction for young learners. The need analysis is employed to detect the relevance of learners' needs and appropriate material for the development of the media. By adapting the development research model by Alessi and Trollip the result of try-out material shows that the product is significantly interactive to boost learners' comprehension. The average score of post-test is better than the pre-test X2 89.67>X1 76. This interactive flashmedia development is, therefore, valid, practical, and effective.

Education, Quality, Redirection, Reevaluation

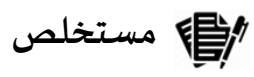

هدف هذا البحث تطوير الوسائل التفاعلية بفليش لتنمية فهم

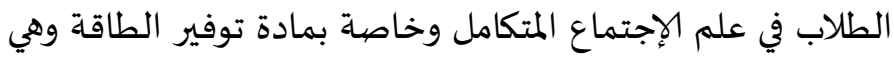

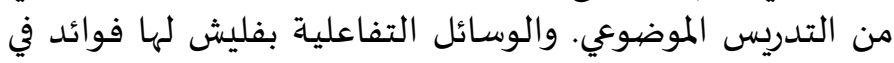

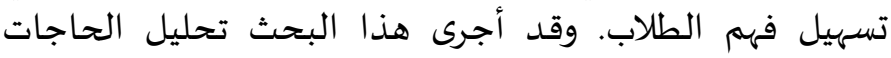
لمعرفة الارتباط بين حاجات الطلاب والوسائل السديد السيدة لديهيه.

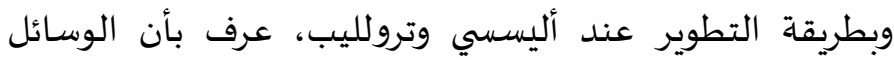
التفاعلية بفليش مناسبة بشخصية الطالب. ودلت نتائج التجربة التبانية

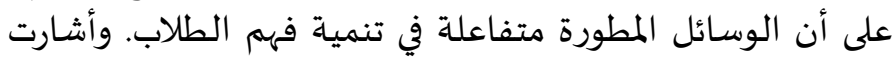

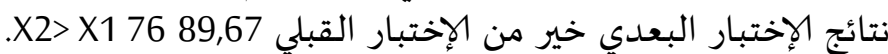

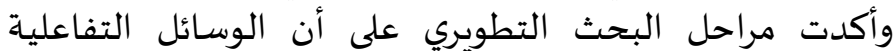
بفليش صحيحة، عملية، وفعالة في التدريس. الوسائل التفاعلية، التدريس الموضوعي، الطلاب الصغار ○.

Citation: Anggraini, Dian Mustika and Muhammad Walid. 2016. Developing Interactive Flash Media for Thematic Learning. Abjadia: International Journal of Education, 1 (1), 16 - 26 


\section{صنافهل ظه \\ International Journal of Education}

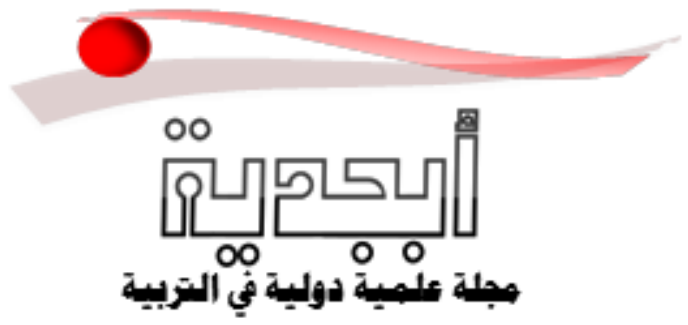

貿" Abstrak

Penelitian ini bertujuan membuat media interaktif berbasis flash untuk meningkatkan pemahaman peserta didik, terutama pada tema hemat energi yang termasuk pembelajaran tematik. Media interaktif berguna memberi kemudahan dalam belajar. Dalam pengembangan ini, analisis kebutuhan dilakukan untuk mendeteksi relevansi antara kebutuhan peserta didik dengan materi pembelajaran agar tepat guna. Penelitian ini menggunakan model Alessi dan Trollip. Hasilnya, media interaktif berbasis flash terbukti sesuai dengan karakter peserta didik. Hasil tes try-out menunjukkan secara signifikan bahwa produk ini terbukti meningkatkan pemahaman peserta didik. Hasil rata-rata post-test lebih baik daripada pre-test 89,67 X2> X1 76. Media interaktif berbasis flash ini tergolong valid, praktis dan efektif dalam menunjang proses pembelajaran

@. Media Interaktif, Pembelajaran Tematik, Peserta Didik Anak-Anak ejournal.uin-malang.ac.id/index.php/abjadia/article/view/3256

\section{(C) INTRODUCTION}

Indonesian government has proposed curriculum 2013 that is appropriate to answer the forthcoming challenge of education. This curriculum has been developed to promote new learning paradigm that is based on some important kernels (1) learnercentered learning (2) interactive learning between teacher and learners (3) learning network (4) active learning (5) study group (6) multimedia based learning (7) development of learner's potential (8) multi discipline (9) critical learning (Jalal, 2001).

These kernels are in agreement with the notion of thematic learning that emphasizes learner's involvement in learning. Thematic learning is very influential for learners' experience of meaningfulness and makes the learning process more effective and interesting (Trianto, 2011). Thematic learning stimulates the teacher to innovatively create either formal or informal activities that are full of meaning, such as empowering learners' learning experience and knowledge to help them understand and perceive the world of life. In other words, the learners should be actively involved in the process of learning and in solving problems.

In the instructional classroom, both of the teachers and the learners will find a lot of benefits from the use of thematic learning. The instructional media that are close to the real life will be fully functioned. Then, learners can easily connect the subject matter they are studying and the learners can develop their cognitive, psychomotor, and affective aspects through group discussion. Besides, the teachers can utilize various active learning strategies in which the learners are able to accommodate various types of intelligences. Therefore, government needs to highlight the application and the evaluation of this learning model so as to be sustainable to implement in the instructional classroom. 
The government can highlight the application of instructional media to support conducive learning situation and condition for the implementation of this learning model. Teachers in globalization era are supposed to be able to utilize the use of technology in the classroom. Hoven (2006) argues that teachers can apply the use of Computer Mediated Communication (CMC) and Computer Assisted Language Learning (CALL).

She also states that numerous teachers and designers have created multimedia applications to help learners understand and make meaning from not just the aural and written language of the target culture, but also some of the visual, social and cultural nuances. Teachers can build the interactivity with the learners not only by using conventional media like images and many more, they can exploit internet, Webcam and other relevant media in instructional classrooms.

Therefore, this research is focused on the development of interactive media to help young learners comprehend certain theme on the thematic learning, namely energy saving. It is because the importance of interactive media in learning environment to optimally motivate the learners' learning interests and competences, the teacher's professional development to use technology, and the harmonic learning sphere that engages teacher's and learner's interactivity. Arsyad (2010) states that the use of media in the process of learning and teaching can generate new interest, passion, motivation, and stimulation of learning activities that the learners' psychology will be affected. He also mentions that designing and developing interactive learning is necessary to help the learners successfully achieve the learning objectives.

There are previous researchers who concern on the issue of CALL and CMC. Tamam (2013) developing computer assisted media on mathematic multiplication material for the fourth grade of elementary school has found out that the media about learning mathematics has good quality and suitable for students. Based on the results of the field trials concluded that computer-assisted mathematics learning media have been already effective, efficient, and attractive to use basic multiplication memorization drills.

The second study on the use of interactive multimedia in social study was conducted by Rohmawati (2014). She concludes that interactive multimedia is able to improve the effectiveness of the study on standards of competence to understand the history, natural appearance and ethnic diversity. The third study of the utilization on Adobe Flash Cs4 to produce thematic media was done by Anshori (2014). He argues that the developement product deserves to be applied in integrative curriculum 2013 at elementary level. 


\section{[Q] SPECIFICATION OF THE PRODUCT}

The product is reading materials and evaluation that are designed into flash player through software I-spring that can change the presentation file into flash and SCORM/AICC. I-spring is commonly used with e-learning LMS (Learning Management System). The application of I-spring can be used to make the evaluation questions and change the Power Point (ppt) files to flash quickly and easily.

Picture 1: the display of the storyboard

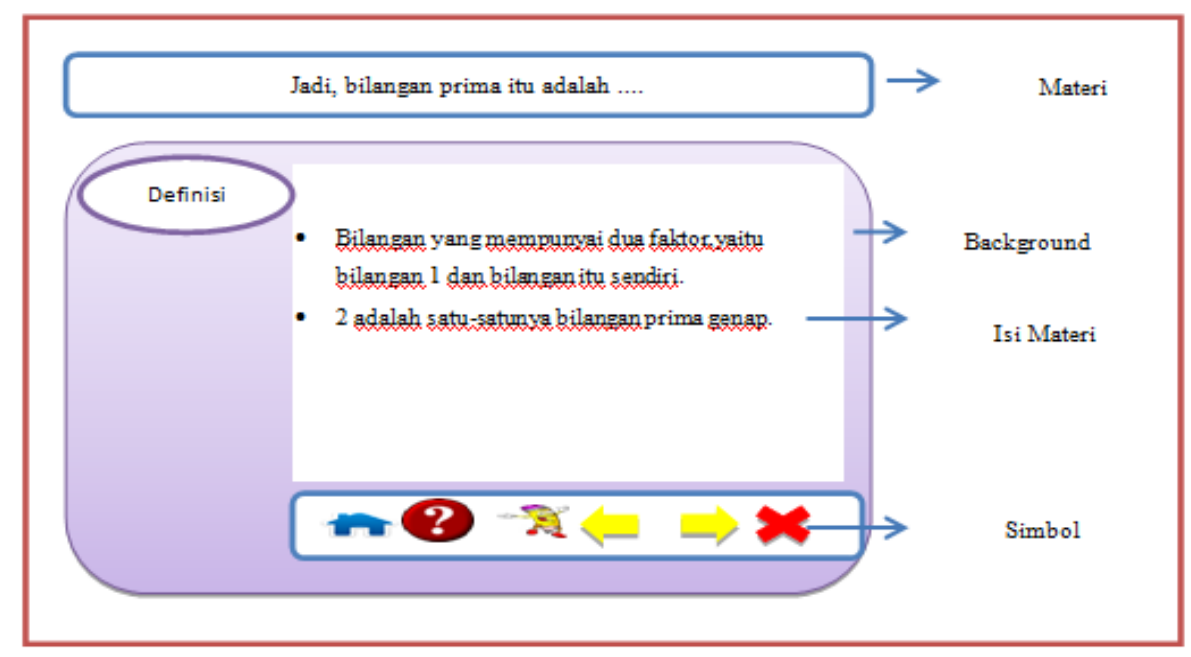

The first step to develop this product is programming the display and menu system in the form of storyboard that can be seen in Picture 1.

Picture 2: the display of the product

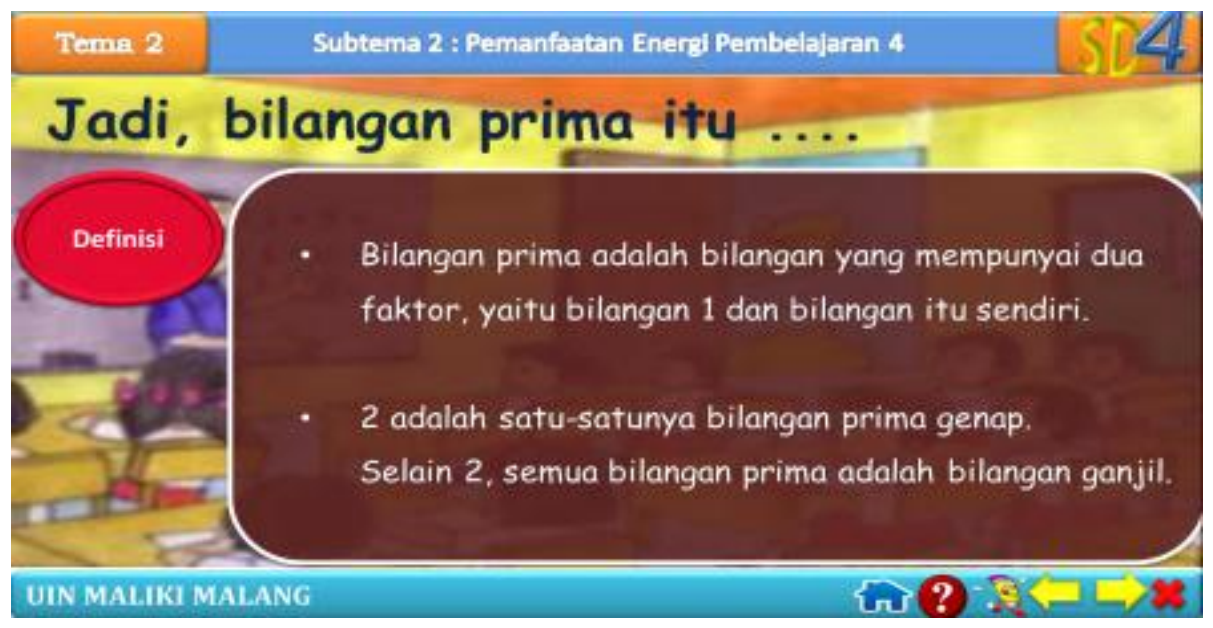

After all storyboard display is programmed, those are moved to computer screen. Then, the contents have to be arranged in ppt. The contents in this interactive media consist of prime number, factor, prime factorization, multiple, solition for multiple problem and chained. If the contents are already prepared, those can be published by clicking tab I-spring and selecting publish menu. Waiting for the process in a second, interactive media of flash player is ready to operate. The result can be seen in Picture 2. 
This product can be converted not only in computer or laptop. It can be operated in android smartphone by converting it from flash swf file to android apk file. To create android applications, the first step is to prepare the needed materials including file results publish I-spring, Android, Adobe air SDK, Java 5.0 and Java 7.0. Due to the flexibility of the flash player in providing reading materials for the students, it is necessary to create supporting materials that include the operating instructions and specifications of computers and Smartphones. The operating instructions can be read when students are already running this interactive media. Students obtain information such as symbol descriptions for instruction, evaluation, home and main menu contained in the media. Instruction symbol is used to inform the function of each symbol. Evaluation symbol is employed to start the test. Home symbol is used to return to the main menu and to select material. The other is cross symbol used to exit the interactive media.

Minimum computer specifications to create android applications from Microsoft Power Point are Intel core 2 duo, 1 Giga memory, Windows vista 2 bits, Microsoft Office 2007 full installation, and flash player 11 upwards. Minimum Smartphone specifications are ARMv7 Processor, OpenGL, 550MHz, Android 2.3 (Gingerbread) upwards, and 256 MB of RAM Memory.

\section{RESEARCH METHOD}

This research was conducted in Islamic Global School, located in Malang-East Java. It was purposively selected since this school has employed Curriculum 2013 as regulated by Indonesia government and has provided proper learning facilities for the researchers to make interactive media. There were 23 learners in grade four that joined try-out of development of instructional materials in which the result of need analysis showed that they had to strengthen their understanding on the learning theme of energy saving. This research adapted the Research and Development model of Alessi and Trolip (1991) because this model is time saving and produces qualified developmental product. This model comprises ten stages of product development, such as (1) determining objectives and needs (2) collecting reference materials (3) learning the content (4) brainstorming (5) designing learning activities (6) creating flowchart (7) creating storyboards (8) material program (9) creating supplementary material and (10) evaluation and revision.

On the evaluation and revision phase, there are four stages to do. In the first stage, the developer consulted drafts of the media to the experts of content, design, and language. The consultation results are analyzed for basis implementation of revised drafts. In phase II, teachers in fourth grade of Islamic Global School Malang were requested to provide feedback and assessment for the material validity. Based on the 
feedback and the assessment of teacher, all components are appropriate. Teacher said interactive media is quite good and needed no revision.

In phase III, media was tested to three students of Islamic global school in the fourth grade. After the test, those three students were interviewed. They argued that the media can be operated easily. In the last phase, the media was tested again to find its effectiveness. There were six students of Islamic global school in the fourth grade who were selected to operate the media. When observed and interviewed, it can be detected that the media had been well utilized. Besides, they understood the learning material easily. Therefore, the fourth step is the last step of product try out.

\section{Learning Practice in the Classroom}

The design of learning media has to attract the students' interest to easily understand the materials such as prime number, prime factorization, least common multiple, and solving problem of LCM. The learning processes for those materials require various learning activities. At the beginning, learners will see the opening menu display and are asked to pray before the study. Afterwards, students click the materials to study in which they will find different symbols of instruction, evaluation, home, and exit.

In the learning process of prime number, the developer directs students to choose the material sequentially. The developer uses numbered tables to facilitate students in finding prime numbers. Students will be involved directly in the game of matching answers. Furthermore, the students are also invited to prove a prime number and not the composite number. After that, students will conclude the definition of primes and give examples of prime numbers.

The second material is factor. The developer can firstly define the factor and prime factors along with examples. Then students are invited to conclude the difference between factors and prime factors. Finally, students were asked to finish a task. The third material is prime factorization. The developer gives definitions and examples of prime factorization to students. Besides, the materials of factor tree are provided interactively.

The fourth material is a multiple of the least common multiple. The developer gives the concept of multiple numbers. Then, students have to observe the multiple number and conclude the definition of multiples of numbers. Here, the developer creates the concept of the animation to make the students easyly understand. After students understand about the least common multiple, they are taught how to determine the least common multiple. Students are taught how to determine least common multiple.

The fifth material is solving the problem of least common multiple. Students are given examples of questions that relate to their daily activities. The developer also 
relates the material with the theme about saving energy. The questions are in the form of matching the answers. The last material is chained. Students are asked to take advantage of second hand objects. Students create a necklace from the second hand materials according to the instructions given.

When the students have finished all of the materials, the students' comprehensions can be evaluated through answering 15 questions in the form of multiple choice. The developer determines that the passing score is 75. If the student's score is below the passing rate, the students should learn more. The score can be known directly after the students answering all the questions because the display will show the score and the review of each question. Consequently, the students can learn and know the explanation of each question. In the end of learning process, students pray together. Then, they can return to the main menu or choose the cross symbol to exit from the media.

\section{Data of Pre-test and Post test}

The average pre-test score was 76 and the average post-tests core was 89.67. It indicates that the average post-test $(89,67)$ is larger than the average pre-test $(76)$. It means that the interactive media is significantly effective to improve the understanding of the material on theme energy saving at fourth grade students in Islamic Global School Malang.

Data pre-test and post-test is analyzed by Paired Sample T-Test. This analytical technique is used to determine the effect on the object of research groups. It implies that there is a difference between cognitive understanding of learners before and after using the media.

\section{Solution:}

$\mathrm{H}_{0}=$ There are no differences in cognitive understanding of learners before and after use the media.

$\mathrm{H}_{\mathrm{a}}=$ There are differences in the cognitive understanding of learners before and after use media.

Because $\mathrm{t}$ count $4,48>\mathrm{t}$ table 1,860 then $\mathrm{Ha}$ is accepted and $\mathrm{H} 0$ is rejected. The conclusion is that there are very significant differences between the value of the final (post-test) and the initial value (pre-test).

\section{Dُفْنَ DISCUSSIONS}

\section{Validity}

Not only does validity from material expert, design expert, linguist, and teacher for developing the media take essential role but also the students' involvement in conducting try-out of the product development is important. There are some scoring 
criteria in product revision including completeness, appropriateness, accuracy of content based on the curriculum 2013, and effectiveness. Those are used for validation to improve the interactive media. Validation results are converted on a percentage scale based on the level of validity and as a basis for decision making to revise interactive media.

\begin{tabular}{|l|l|l|}
\hline Percent $\mathbf{( \% )}$ & Valid & Description \\
\hline $80-100$ & Valid & No Revision \\
\hline $60-79$ & Valid & No Revision \\
\hline $40-59$ & Less Valid & Need revision \\
\hline $0-39$ & Very less Valid & Need revision total \\
\hline
\end{tabular}

Based on a conversion scale, the scoring criteria of the product are elaborated as follows:

Score 1: very inappropriate, very less readable, very less accurate, very poorly organized, very ugly, very poor, very less substantial

Score 2: less appropriate, less readable, less accurate, less regular, less excellent, less capable, and less substantial

Score 3: appropriate, readable, accurate, regular, excellent, capable, and substantial

Score 4: very appropriate, very readable, very accurate, very regular, very excellent, very capable, and very substantial

Based on the validity from the material expert, the design expert, the linguists, and the teacher, it can be detected that all components are valid and feasible. The validity show significant results, material expert $(81,25 \%)$, the design expert $(98,00 \%)$, the linguist $(100 \%)$, and teacher $(89,57 \%)$. The percentages imply that interactive media is ready to be used by students and teachers in instructional classroom. In addition, the students give their positive response because the media look interesting, nice, colorful, and easy to understand. The individual test phase I and phase II reveal good achievement. The former is $91 \%$, the latter is $98 \%$. Therefore, interactive media theme energy saving at fourth grade in Islamic global school Malang is valid. Mustofa dkk (2011) states that a media development is effective and efficient if it has been proven in the field, not just theoretical (Mustofa dkk.,2011).

\section{Practicality}

Interactive media theme energy saving can be functioned as a reference for teachers and students in the process of learning energy saving theme. It is packaged in a very attractive look that can invite the students to understand the concept clearly. Students feel more happy and excited in learning with this interactive media. They also look more enthusiastic when this interactive media is operated on their own smartphones. In accordance with constructivism, Warsita (2008) argues that a process of knowledge construction by students is dealing with active activities, active thinking, 
forming concepts and bringing meaningfulness. Therefore, interactive media can foster a desire, interest, motivation and stimulation of learning activities, and provide psychological influences to the students. It also strengthened the effective function of learning media that appropriate learning media can enhance the admission of students to a particular stimulus.

Interviewed by the developer, the students argue that they are interested in learning using flash media player. They said that:

"The media are great. I like. It looks colorful."

"I feel very good when studying. If every day is like this, I am so passion when learning. I won't be sleepy"

The development product is designed in colorful look to vary each material being studied. Each display provides the menu to return to the home page, direction, evaluation, and exit buttons if they want it at any time. Beside, it is supported by a sound that can stimulate the student's listening skill. Appropriate learning media are learning media that capable to attract and focus the attention of the students (Munadi, 2012).

\section{Effectiveness}

The interactive media proved to be significantly effective to improve the understanding of the material on theme energy saving at fourth grade students in Islamic Global School Malang. Because $t$ count 4,48 $>\mathrm{t}$ table 1,860 then Ha is accepted and $\mathrm{HO}$ is rejected. The conclusion is that there are very significant differences between the value of the final (post-test) with the initial value(pre-test). Furthermore, from the average is known $\mathrm{X} 289.67>\mathrm{X} 176$, means that the value of the post-test better than the pre-test. So there are significant differences in cognitive understanding of students on media development have been developed. It means that interactive media development can add to the diversity of thematic media on curriculum 2013. Media can solve issues such as differences in learning styles, interests, intelligence, sense of power limitation, disability or geographical distance, time (Sardiman, 2014).

\section{Strengths and Weaknesses of the Developed Media}

This interactive media development has advantages and weakness. The advantages of this interactive media are:

a. Students more easily understand the material on the theme energy saving because the material can be presented as attractive as possible with animation

b. The main purpose of this interactive media is to help students and teacher in the learning process to enhance student's understanding of the themes energy saving 
c. This interactive media can be used by teachers to support the learning process. The teacher only guides and assist students in using this media

d. Interactive media is very applicable to the environment students. Students not only learn about the material on the three subjects, but students also can apply the material in everyday life. Because the developers give examples of problems around their environment. It supports cognitive function of learning media that the more object is seen, so the more thoughts and ideas that are owned or are getting rich and extensive nature of their cognitive

e. This interactive media can be used in your computer using an LCD, besides students and teachers can also use this media to a Mobile device. So, whenever they want to learn, unlimited by time and place. As long as there is a supervisor when studying this media

f. The media could also be transferred via Bluetooth on any Android phone.

On the other hand, the interactive media has some weaknessses, such as:

a. Only one study on the theme energy saving subtheme energy utilization fourth learning

b. This interactive media does not increase the value of students drastically because the goal of the developer is to understand the concept of material in the theme energy saving

c. Sound in interactive media sometimes do not match with a slide that is being opened

d. Interactive media can only be used on a computer or a mobile phone that has certain specifications.

Although this interactive media theme energy saving has weaknesses, it is valid, effective and efficient.

\section{CONCLUSION}

A great teacher must know what is the necessary for student. One of which is selecting right media. Media is one way to send information to student. This interactive media need improve to be better. For others researcher who interest to development this media can develop the material. Because this interactive media only develop one learning in one theme. The teacher must be able to operate computer because this media related with it. Researcher hope that this interactive not only is used in one school but also all of school used this media.

\section{BIBLIOGRAPHY}

Anshori, N. 2014. The Development of Thematic Integrative Learning Media Using Adobe Flash Cs4 For 1st grade of State Islamic Elementary School Malang 2. Skripsi. Jurusan PGMI, FITK, UIN Maulana Malik Ibrahim Malang. 
Arsyad, A. 2010. Media Pembelajaran. Jakarta: Rajawali Press

Debra, H. 2006. Communicating and Interacting: An Exploration of the Changing Roles of Media in CALL/CMC. Computer Assisted Language Instruction Consortium Journal 23(2):(233-256) accessed from http:/ / eprints.qut.edu.au, July 8th, 2015.

Jalal, F. 2001. Reformasi Pendidikan Dalam Konteks Otonomi Daerah. Yogyakarta: Adicita

Mamat S. B. 2005. Pedoman Pelaksanaan Pembelajaran Tematik. Jakarta: Direktorat Jenderal Kelembagaan Agama Islam.

Munadi, Y. 2012. Media Pembelajaran Sebuah Pendekatan Baru. Jakarta: Gaung Persada Press

Mustofa, M. T. \& Arif. 2011. Belajar \& Pembelajaran. Jakarta: Ar-Ruzz media

Peraturan Menteri Pendidikan dan Kebudayaan Nomor 67 Tahun 2013 tentang Kerangka Dasar dan Struktur Kurikulum Sekolah Dasar/Madrasah Ibtidaiyah

Rohmawati, A. 2014. Pengembangan Multimedia Pembelajaran Interaktif untuk Meningkatkan Keefektifan Pembelajaran pada Materi Sejarah, Kenampakan Alam dan Keragaman Suku Bangsa untuk Siswa Kelas IV A MI Miftahul Ulum Kota Batu. Skripsi. Jurusan PGMI, FITK, UIN Maulana Malik Ibrahim Malang.

Sardiman. 2011. Interaksi \& Motivasi Belajar Mengajar. Jakarta: Raja Gravindo Persada

Tamam, C. A. B. 2013. Pengembangan Media Pembelajaran Matematika Materi Perkalian Bilangan Bulat Berbantuan Komputer untuk Siswa Kelas IV SD/M. Skripsi. Jurusan PGMI, FITK, UIN Maulana Malik Ibrahim Malang.

Trianto. 2011. Desain Pengembangan Pembelajaran Tematik. Jakarta: Kencana Prenada Media Group

Trollip, A. 1991. Computer Based Instruction: Methods and Development. New Jersey: Prantice Hall

Warsita, B. 2008. Teknologi Pembelajaran, Landasan dan Aplikasinya. Jakarta: Rineka Cipta

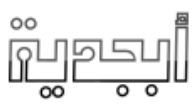

